\title{
Terminalioxylon edwardsii from the Oligocene of Egypt, with a review of the genus in Africa
}

\author{
W. E. El-Saadawi, M. M. Kamal El-Din, M. W. El-Faramawi \\ and N. A. Ziada ${ }^{1}$
}

Botany Department, Faculty of Science, Ain Shams University, Cairo, Egypt. ${ }^{1}$ Corresponding author

E-mail addresses: wagelsaadawi@yahoo.com,

marwah_kamal@hotmail.com, m.elfaramawi@yahoo.com, nermeenziada@yahoo.com

W. E. El-Saadawi, M. M. Kamal El-Din, M. W. El-Faramawi and N. A. Ziada 2013. Terminalioxylon edwardsii from the Oligocene of Egypt, with a review of the genus in Africa. Taeckholmia 33: 47-63.

\begin{abstract}
$\boldsymbol{p}$ etrified wood resembling modern wood of Terminalia (Combretaceae) is described from the Oligocene of the Cairo Petrified Forest, Egypt. On the bases of xylotomical homologies, the fossil wood is attributed to Terminalioxylon edwardsii. A summary is given on Terminalioxylon and Combretaceae, with inferences on palaeoclimate.
\end{abstract}

Key words: Oligocene, Egypt, fossil wood, Combretaceae, Africa, palaeoclimate.

\section{Introduction}

The Oligocene epoch (34-23 million years ago) was the last major geologic subdivision of the Paleogene period (65-23 million years ago), following the Paleocene (65-56 million years ago) and Eocene (56-34 million years ago) epochs. It represents a transitional period within plant evolution stages where climate conditions changed and new environments began to form (www.stratigraphy.org).

Received 6 Feb. 2014, accepted 26 feb. 2014 
The majority of African plant fossils consists of pollen assemblages and petrified wood (Pan, 2007). To date, about 400 dicot fossil woods have been recorded from Africa (Gros, 1992; Dupéron-Laudoueneix \& Dupéron, 1995; Gregory et al., 2009; El-Saadawi et al., 2011; Cantrill et al., 2013); represented in the fossil record from the Cretaceous to the Quaternary. Fossil wood is mostly scattered across North Africa, but in some cases the age and taxonomic affinity may not be well known or are questionable (Pan, 2007).

The Oligocene dicot wood flora of Africa is represented by 43 taxa, with affinities to fourteen families: Fabaceae (14 species), Combretaceae (six species), Moraceae (five species), Meliaceae (four species), Clusiaceae, Ebenaceae, Euphorbiaceae, Malvaceae (two species each), Fagaceae, Juglandaceae, Monimiaceae, Sapindaceae, Tamaricaceae and Opiliaceae (one species each) (Dupéron-Laudoueneix \& Dupéron, 1995; Gregory et al., 2009; El-Saadawi et al., 2011).

Oligocene dicot woods recorded from Egypt reach a total of 22 taxa (Table 1); which contributes just over $50 \%$ of the total Oligocene woods recorded from Africa. These fossil woods are known from 17 Egyptian sites, with 19 taxa being reported from the Cairo Petrified Forest (CPF) at Qattamiya (Fig. 1).

As shown in Table (1), the 22 Egyptian Oligocene dicot wood taxa are assigned to nine families namely Fabaceae (ten species), Combretaceae (three species), Malvaceae and Moraceae (two species each), Ebenaceae, Fagaceae, Monimiaceae, Sapindaceae and Tamaricaeae (one species each).

The aim of this paper is to report on the occurrence of a fossil wood species attributed to family Combretaceae, for the first time, in the Oligocene CPF at Qattamiya, to give a summary of fossil Terminalioxylon and Combretaceae and finally, to try to reconstruct palaeoclimate of the original growth site of the discussed species; taking into account the ecological and distributional characteristics of its nearest living relative. 


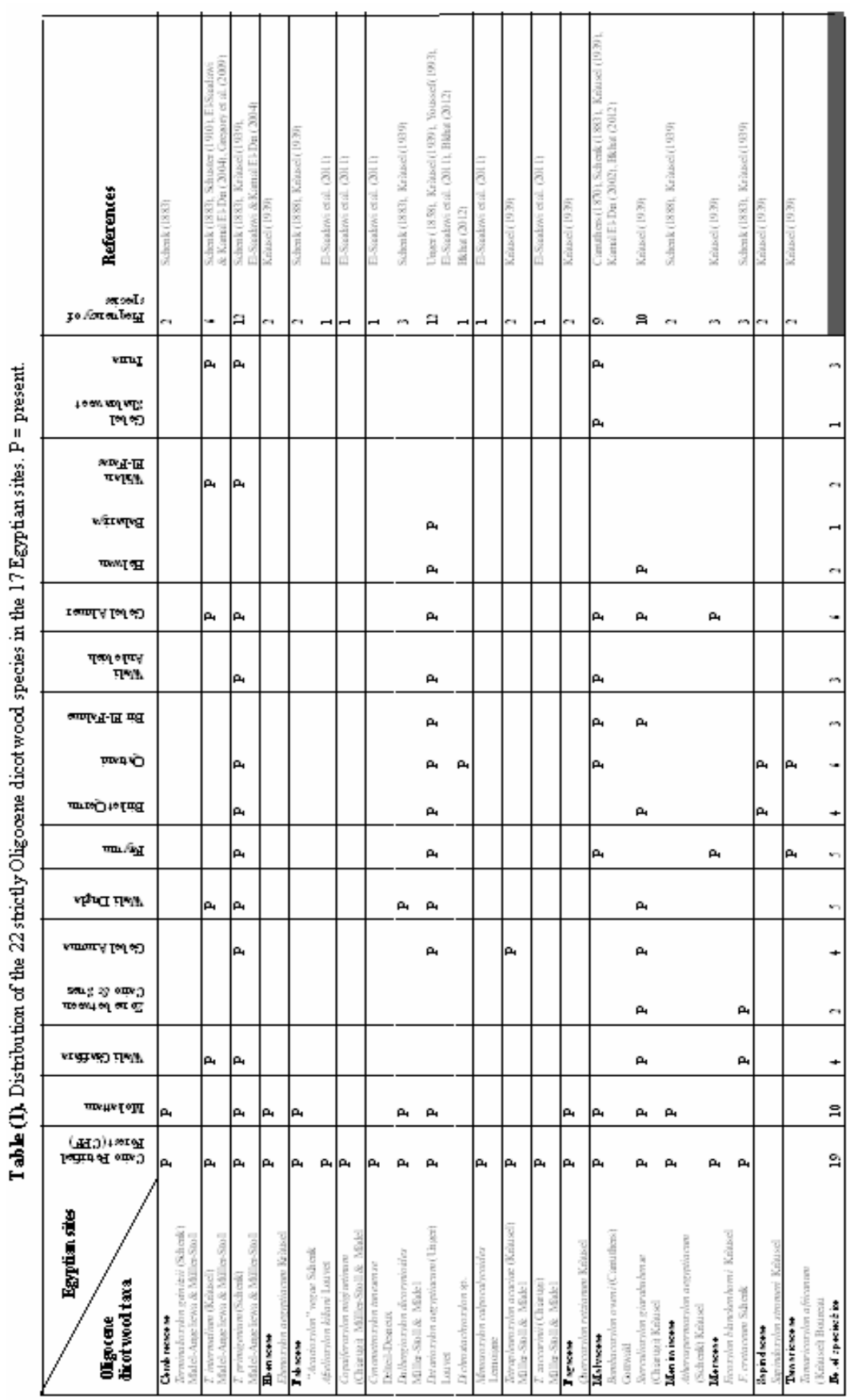




\section{Materials and Methods}

\section{Geographic occurrence}

Located in the desert hills of Qattamiya, southeast of Cairo and extending for tens of kilometers in the desert towards Suez in the east, the Petrified Forest is a geological protected area comprising only about $7 \mathrm{~km}^{2}$ between latitudes $29^{\circ} 58^{\prime} 30^{\prime \prime}$ and $29^{\circ} 59^{\prime} 40^{\prime \prime} \mathrm{N}$ and longitudes $31^{\circ} 27^{\prime} 30^{\prime \prime}$ and $31^{\circ} 28^{\prime} 30^{\prime \prime} \mathrm{E}$, found in New Cairo City about $20 \mathrm{~km}$ east of Old Cairo and only $1 \mathrm{~km}$ from the old toll station on Al-Qattamiya-Al-Sokhna highway (El-Saadawi et al., 2011) (Fig. 1). The protected area is denser in fossil trunks than its extended tributaries and is therefore known as Gebel El-Khashab or 'Wood Hill'.

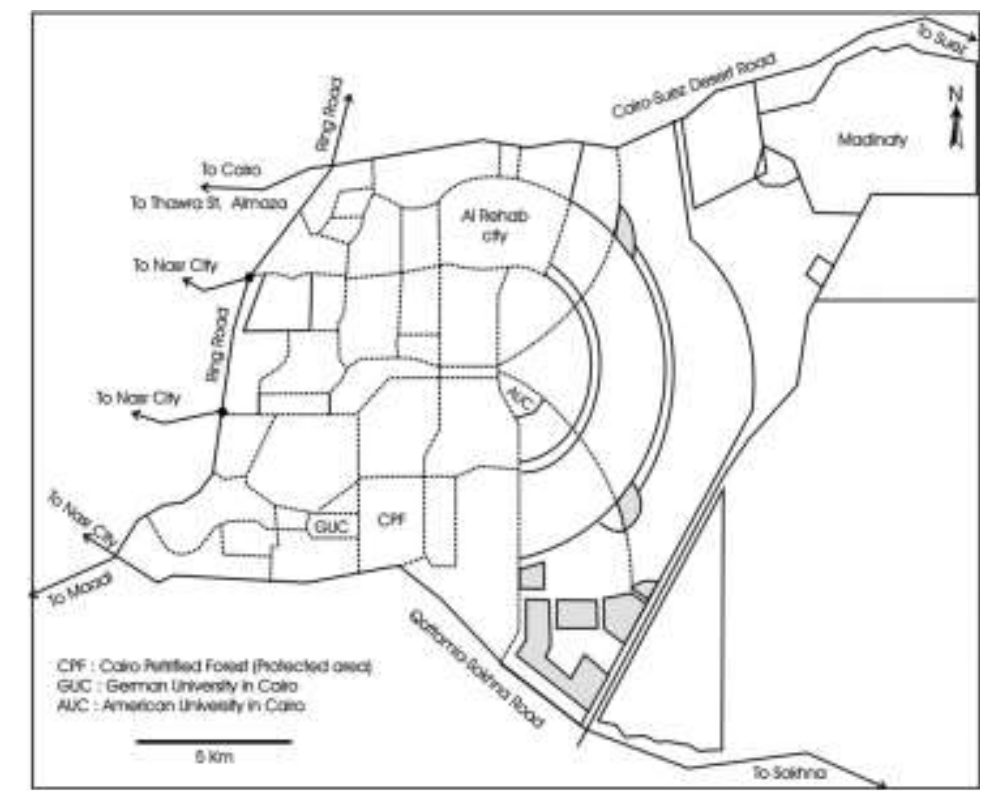

Fig. 1. Map showing location of the protected area (CPF) after El-Saadawi et al. (2011).

The protected area does not resemble a forest in the common sense, but is rather characterized by tree trunks and chunks of wood said to be petrified and fossilized over the course of more than 35 million years and therefore the Eocene/Oligocene age of the CPF given in Kappelman et al. (1992) and followed by El-Saadawi et al. (2011) is corrected here to early Oligocene (34-23 million years ago) as stated earlier by many geologists (e.g. Said, 1971). 


\section{Collection and sample preparation}

The specimens used in this study were collected during a field excursion on $21^{\text {st }}$ of June 2012. All the specimens were collected from inside the protected area borders. They vary in size from 5 to $20 \mathrm{~cm}$ in length. Some of them were collected from large logs (ranging in length from 1 to $25 \mathrm{~m}$ and in diameter from 0.2 to $1.6 \mathrm{~m}$ ) after chopping them off in the field. The rest of the samples were already loose fragments.

Cross, tangential and radial longitudinal sections were obtained using a standard thin-section technique following the procedure described by Andrews (1961) and Kamal El-Din (1996). The sections were studied using a light microscope and photographed with an attached Canon PowerShot G12 digital camera. All images were then post-processed using Adobe Photoshop CS.

All the fossil specimens and the prepared slides are numbered ${ }^{1}$ and deposited in the palaeobotanical collection of the Palaeobotany Unit, Botany Department, Faculty of Science, Ain Shams University, Cairo, Egypt.

\section{Sample description and identification}

The descriptions have mostly been made according to the International Association of Wood Anatomists Committee recommendations (IAWA Committee, 1989). Affinities were determined by consulting the literature (e.g. Metcalfe \& Chalk, 1950) and searches in the online wood database Insidewood (2004-onwards). Relevant fossil wood genera were discussed in light of the comprehensive survey of fossil woods (Gregory et al., 2009). Systematic assignment follows the APG III (2009).

\section{Results and Description}

Microscopic examination revealed that the preservation of the collected specimens is satisfactory to good. However, only sample $8 \mathrm{NZ}$ was identified as Terminalioxylon edwardsii (Kräusel) Mädel-Angeliewa \& Müller-Stoll, whilst the remaining ones need further investigation.

Systematic palaeobotany

Family: Combretaceae Robert Brown

Genus: Terminalioxylon Schönfeld, 1947 emend Mädel-Angeliewa \& Müller-Stoll, 1973

\footnotetext{
${ }^{1}$ The number is followed by the initials of the collector, where NZ refers to Nermeen Ziada.
} 
Generic diagnosis- Growth rings distinct or indistinct, marginal parenchyma sometimes present, vessels solitary or in short to long radial multiples (up to 14 vessels), perforation plates simple, intervessel pits alternate, fibres septate or non-septate, axial parenchyma paratracheal, vasicentric narrow to broad, often more or less aliform, seldom also confluent, chambered crystalliferous strands present or absent, rays 1(-2) cells wide, homocellular or weakly heterocellular, solitary crystals frequently present, mostly in enlarged square to upright cells in rows in between procumbent ray cells (Mädel-Angeliewa \& Müller-Stoll, 1973; ElSaadawi et al., 2014).

Species: Terminalioxylon edwardsii (Kräusel) Mädel-Angeliewa \& MüllerStoll, 1973 (Leguminoxylon edwardsi Kräusel, 1939)

Specimen No. 8NZ; Plate I, 1-5

Description- Growth rings indistinct or absent. Wood diffuse-porous. Vessels mainly solitary (73\%) and in radial multiples of 2-4 (27\%); mean tangential diameter of $95 \mu \mathrm{m}$ (range $65-130 \mu \mathrm{m}$ ), mean radial diameter of $210 \mu \mathrm{m}$ (range 150-280 $\mu \mathrm{m}$ ); average vessel frequencies of $5 / \mathrm{mm}^{2}$ (range 3$8 / \mathrm{mm}^{2}$ ). Perforation plates simple with horizontal end-walls. Intervessel pits alternate. Mean vessel element length $250 \mu \mathrm{m}$ (range 190-320 $\mu \mathrm{m}$ ), medium-sized. Fibres non-septate and thin- to thick-walled. Axial parenchyma vasicentric, weakly aliform, sometimes confluent connecting two vessels together.

Diffuse parenchyma cells also present. Rays homocellular, composed of procumbent cells; exclusively uniseriate; non-storied, mean height is 180 $\mu \mathrm{m}$ (range $90-390 \mu \mathrm{m}$ ).

\section{Comparisons, Affinities and Discussion}

The diagnostic anatomical characteristics of the fossil wood are: absence of growth rings, diffuse porous wood, mostly solitary vessels, simple perforation plates, alternate intervessel pits, vasicentric, weakly aliform, sometimes confluent, including diffuse axial parenchyma and exclusively uniseriate rays.

The combination of these features may occur in woods of families Anacardiaceae, Combretaceae, Fabaceae and Sapindaceae. However, the absence of large vessels of ring porous type and gum canals excludes Anacardiaceae; of abundant paratracheal parenchyma and generally multiseriate rays excludes Fabaceae and of mostly scanty parenchyma excludes members of Sapindaceae. The above affinities therefore point to family Combretaceae (Ahmed et al., 2007). 
All the above described characters indicate close affinity with the extant species of Terminalia Linnaeus. All fossil woods resembling Terminalia are assigned to the genus Terminalioxylon which was established by Schönfeld (1947) [emended by Mädel-Angeliewa \& Müller-Stoll (1973)]. Since then, a number of fossils have been described under this genus to reach a total of 51 species worldwide (De Franceschi et al., 2008; Castañeda-Posadas et al., 2009; Gregory et al., 2009). Comparison between the 51 species is difficult as many of them are based on poorly preserved samples, and figures frequently do not clearly show important distinguishing features.

Species of Terminalioxylon were spread in four continents ${ }^{2}$ (35 species in Asia, 11 species in Africa (Table 2), 6 species in South America and one species in North America). Each continent had its own distinct species, i.e. not found in other continents except for only two species, namely $T$. chowdhurii and T. intermedium, which were found to be common between Asia and Africa.

Considering the African Terminalioxylon species (Table 2), it is clearly evident from the data presented that:

1. Terminalioxylon was reported from nine countries and had a long vertical time span from the Cretaceous to Pliocene/Quaternary.

2. T. geinitzii and T. intermedium were the oldest species; both are from the Cretaceous of Somalia, in addition T. intermedium exists as well in the Cretaceous of Egypt.

3. T. intermedium is the most widespread species as it had been noted from six countries. Table (1) showed that this species is also widespread in Egypt, but second to T. primigenium.

4. Only three species, namely $T$. geinitzii, $T$. intermedium and $T$. primigenium are reported from more than one country.

5. Egypt, Ethiopia and Libya have the greatest number of Terminalioxylon species (four species each), followed by Somalia (three species) (Fig. 2).

6. It is noticeable that the Terminalioxylon floras of Egypt, Libya and Somalia were similar to one another.

${ }^{2}$ De Franceschi et al. (2008) stated that Terminalioxylon was reported from the Tertiary deposits of Europe but neither the reference nor the species recorded are documented. 
Table (2). Age and distribution of Terminalioxylon species in Africa. Based on 1Schenk, 1883; 2- Schuster, 1910; 3- Chiarugi, 1933; 4- Kräusel, 1939; 5Boureau, 1955; 6- Boureau, 1958; 7- Louvet, 1973; 8- Lemoigne et al., 1974; 9Lemoigne, 1978; 10- Fessler Vrolant, 1980; 11- Boureau et al., 1983; 12Youssef, 1993; 13- Bamford, 1999; 14- El-Saadawi \& Kamal El-Din, 2004; 15present work. $\mathrm{K}=$ Cretaceous, $\mathrm{T}=$ Tertiary, $\mathrm{E}=$ Eocene, $\mathrm{O}=$ Oligocene, $\mathrm{M}=$ Miocene, $\mathrm{P}=$ Pliocene, $\mathrm{Q}=$ Quaternary; $\mathrm{S}=$ South.

\begin{tabular}{|c|c|c|c|c|c|c|c|c|c|c|}
\hline \multirow[t]{2}{*}{ Taxa } & \multicolumn{9}{|c|}{ Country } & \multirow[b]{2}{*}{ 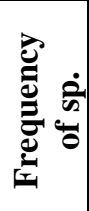 } \\
\hline & 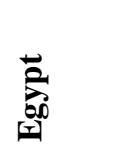 & 疍 & 覀 & $\frac{\pi}{\overbrace{0}^{0}}$ & 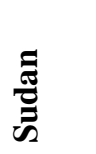 & $\sum_{\bar{\sigma}}^{\bar{\sigma}}$ & 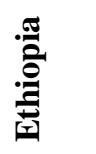 & 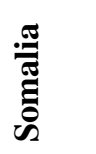 & 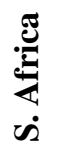 & \\
\hline $\begin{array}{l}\text { Terminalioxylon cheidense } \\
\text { Fessler Vrolant }\end{array}$ & & & O10 & & & & & & & 1 \\
\hline $\begin{array}{l}\text { T. chowdhurii Prakash \& } \\
\text { Navale }\end{array}$ & & & & & & & & & M13 & 1 \\
\hline T. doubingeri Lemoigne & & & & & & & M9 & & & 1 \\
\hline T. edengense Boureau & & & & & & T5 & & & & 1 \\
\hline $\begin{array}{l}\text { T. edwardsï (Kräusel) } \\
\text { Mädel-Angeliewa \& Müller- } \\
\text { Stoll }\end{array}$ & $\begin{array}{l}\mathrm{O} 15 \\
\mathrm{O} / \mathrm{M} 4\end{array}$ & & & & & & & & & 1 \\
\hline T. fezzanense Boureau & & O6 & & & & & & & & 1 \\
\hline $\begin{array}{l}\text { T. geinitizii (Schenk) Mädel- } \\
\text { Angeliewa \& Müller-Stoll }\end{array}$ & $\begin{array}{c}\mathrm{O} 11,14 \\
\mathrm{O} / \mathrm{M} 4 \\
\mathrm{M} 12\end{array}$ & $\mathrm{O} 7$ & & & & & & $\begin{array}{l}\mathrm{K} 3 ; \\
\mathrm{O} / \mathrm{M} 7\end{array}$ & & 3 \\
\hline $\begin{array}{l}\text { T. intermedium (Kräusel) } \\
\text { Mädel-Angeliewa \& Müller- } \\
\text { Stoll }\end{array}$ & $\begin{array}{c}\text { K4; } \\
\text { K/E11; } \\
\text { O7, 11, } \\
\text { 14; M12 }\end{array}$ & $\begin{array}{l}\text { K/E11; } \\
\text { M11 }\end{array}$ & & $\mathrm{K} / \mathrm{E} 11$ & $\mathrm{~K} / \mathrm{E} 11$ & & $\mathrm{~K} / \mathrm{E} 11$ & $\begin{array}{l}\text { K11; } \\
\text { M11 }\end{array}$ & & 6 \\
\hline $\begin{array}{l}\text { T. primigenium (Schenk) } \\
\text { Mädel-Angeliewa \& Müller- } \\
\text { Stoll }\end{array}$ & $\begin{array}{c}\mathrm{O} 1,4,14 \\
\mathrm{O} / \mathrm{M} 7 \\
\mathrm{M} 2\end{array}$ & $\mathrm{O} / \mathrm{M} 7$ & & & & & & $\mathrm{O} / \mathrm{M} 3$ & & 3 \\
\hline $\begin{array}{l}\text { T. sp.of Lemoigne, } \\
\text { Beauchamp \& Samuel }\end{array}$ & & & & & & & M8 & & & 1 \\
\hline$T$. sp.of Lemoigne & & & & & & & P/Q9 & & & 1 \\
\hline No. of taxa/ country & 4 & 4 & 1 & 1 & 1 & 1 & 4 & 3 & 1 & \\
\hline
\end{tabular}




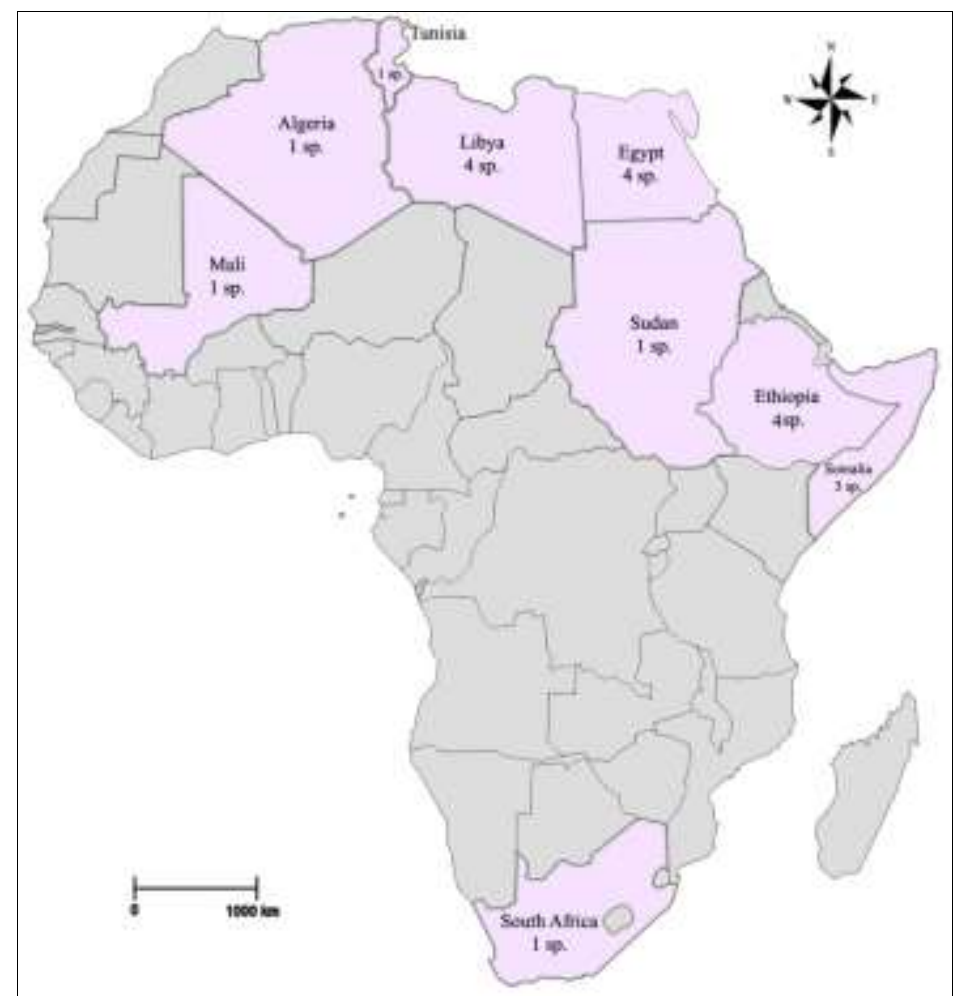

Fig. 2. Map showing the geographic distribution of Terminalioxylon and the number of species in African countries. sp. = species.

As shown in Table (2), four Terminalioxylon species are reported from Egypt, namely T. edwardsii, T. geinitzii, T. intermedium and T. primigenium. Table (1) shows that $T$. primigenium is the most widespread species of this genus in Egypt (12 sites), followed by $T$. intermedium (six sites) then T. geinitzii (two sites). The present work and Table (2) show that $T$. edwardsii occurs also in two sites, from the Oligocene of the CPF (present work) and from the Oligocene/Miocene of Giza Pyramids (Kräusel, 1939).Tables (1) and (2) show also that $T$. primigenium occurs in all the sites in which the other three species of the genus exist and that the CPF at Qattamiya is, hitherto, the only site in which the four species are known to exist together. Table (3) includes a comparison between $T$. edwardsii reported from the Giza Pyramids and the present specimen, where it is clearly evident that both specimens are anatomically similar, although slight differences in the quantitative features are noticed. 
Table (3). Comparison between T. edwardsii described by Kräusel (1939) and the studied specimen $8 \mathrm{NZ}$.

\begin{tabular}{|c|c|c|}
\hline \multirow[t]{2}{*}{ Features } & T. edwardsii & 8NZ \\
\hline & $\begin{array}{c}\text { Giza Pyramids } \\
\text { (Oligocene/Miocene) } \\
\text { Kräusel, 1939 }\end{array}$ & $\begin{array}{c}\text { Cairo Petrified Forest } \\
\text { (Oligocene) } \\
\text { Present Work }\end{array}$ \\
\hline Vessels & $\begin{array}{l}\text { Solitary \& in radial multiples of } \\
2-3 \text { (rarely } 4 \text { ) }\end{array}$ & $\begin{array}{l}\text { Solitary }(73 \%) \& \text { in radial } \\
\text { multiples of } 2-4(27 \%)\end{array}$ \\
\hline $\begin{array}{l}\text { Vessel tangential } \\
\text { diameter }\end{array}$ & $65-100 \mu \mathrm{m}$ & 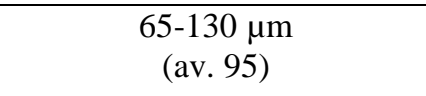 \\
\hline Vessel frequency & $4-16 / \mathrm{mm}^{2}$ & $3-8 / \mathrm{mm}^{2}$ \\
\hline $\begin{array}{l}\text { Vessel element } \\
\text { length }\end{array}$ & $150-450 \mu \mathrm{m}$ & $\begin{array}{c}190-320 \mu \mathrm{m} \\
(\mathrm{av} .250)\end{array}$ \\
\hline Axial Parenchyma & $\begin{array}{l}\text { Aliform, sometimes confluent } \\
\text { between two vessels, diffuse } \\
\text { parenchyma cells present }\end{array}$ & $\begin{array}{l}\text { Vasicentric, weakly aliform, } \\
\text { sometimes confluent between } \\
\text { two vessels, diffuse } \\
\text { parenchyma cells present }\end{array}$ \\
\hline Ray width & $\begin{array}{l}\text { Mostly uniseriate, rarely } 2-(3) \\
\text { seriate }\end{array}$ & Exclusively uniseriate \\
\hline
\end{tabular}

This is the first report of this species from the study area which sums up the dicot species revised previously by Gregory et al. (2009) and ElSaadawi et al. (2011) from the CPF to reach a total of 20 species belonging to the following seven families: Fabaceae (nine species), Combretaceae (four species), Malvaceae and Moraceae (two species each), Ebenaceae, Fagaceae and Monimiaceae (one species each). Family Combretaceae is therefore the second largest dicot family (following Fabaceae) not only in the CPF or even Egypt but also in the African continent at large (DupéronLaudoueneix \& Dupéron, 1995; El-Saadawi et al., 2011). Seven combretaceous genera are reported from Africa (asterisked below) in addition to three unnamed fossil woods, from a total of twelve represented in the world at large, namely Angeissoxylon, Angeissus, Angeissuoxylon*, cf. Buchenavia, Combretoxylon*, Combretum*, Lumnitzeroxylon, Terminalia*, cf. Terminalia, cf. Terminalioxylon*, Terminalioxylon* and Pteleopsis* (Dupéron-Laudoueneix \& Dupéron, 1995; Gregory et al., 2009; El-Saadawi et al., 2014). The largest of these genera is Terminalioxylon (51 spp.). Three combretaceous genera are known from Egypt, namely Terminalioxylon, cf. Terminalioxylon and Combretoxylon. Combretoxylon 
sp. of Beauchamp, Lemoigne \& Petrescu was reported to occur in the Miocene of Egypt by Boureau et al. (1983) without mentioning a locality (Dupéron-Laudoueneix \& Dupéron, 1995; El-Saadawi \& Kamal El-Din, 2004) whereas cf. Terminalioxylon edwardsii was described from the Miocene of Cairo-Bahariya Oasis Desert Road (El-Saadawi et al., 2014). In addition to the woods, a combretaceous leaf species Terminaliophyllum africanum Lejal-Nicol, was recorded from the Eocene of Suez by LejalNicol (1987).

\section{Palaeoclimatic reconstruction}

Members of present day Combretaceae are noted to occur throughout the tropical and subtropical regions with a limited spread into warm temperate zones. The family is particularly more diverse along tropical seacoasts, in African savannas and in Asian monsoon forests (Singh et al., 2011).

The study of fossil plants to shed light and reconstruct past climates has long been practiced. One of the most favoured methods to infer past conditions is to apply the environmental envelope of the Nearest Living Relative (NLR), which assumes that the fossil taxon has a similar climatic tolerance and habitat to its NLR. The modern counterpart of the identified fossil is Terminalia (as mentioned earlier). This genus consists of about 150 species of large trees widely distributed in the tropical regions of both hemispheres (Tiwari et al., 2012) in dry deciduous forests and savannas. Considering the modern distribution, the fossil wood indicates a tropical climate unless the species has been adopted to a different climate by the lapse of millions of years.

Xylotomical characters are also reliable indicators for palaeoclimatic interpretation as plants have a direct relationship with their environment and climatic change is encoded in physiognomic change. The main physiognomic features of the described wood (absence of growth rings, diffuseporous wood, simple perforation plates, low vessel densities, non-storied homocellular uniseriate rays and abundance of axial parenchyma) indicate a subtropical to tropical non-seasonal climate. In contrast, woods growing in temperate regions show narrow vessel diameters $(<100 \mu \mathrm{m})$, high vessel densities, storied heterocellular thick rays and absence of axial parenchyma (Wiemann et al., 2001; Shukla et al., 2013).

Palaeoclimatic inferences derived from the fossil woods in the absence of other plant remains such as roots, twigs, leaves, seeds and fruits may not be very reliable because woods are usually transported before preservation (Shukla et al., 2013). Consequently, the wood physiognomic features of the 
fossil cannot be taken as an indication of the climate at the locality, but of the site of growth.

Wolfe and Upchurch (1987) used Carlquist's vulnerability index (1975) for measuring the susceptibility or vulnerability of wood to water shortage or drought conditions. The high ' $\mathrm{V}$ ' (vulnerability) value (= mean vessel tangential diameter/ mean number of vessels per $\left.\mathrm{mm}^{2}\right)$ of $19(95 / 5$, see description)reported for the specimen under study suggests that the tree grew in an area of low water stress and that the tree was large because large trees have higher ' $V$ ' values than small trees and shrubs (Carlquist, 1988). A high ' $M$ ' (mesomorphy) index (= V x mean vessel element length) of 4750 $(19 \times 250$, see description) further indicates a mesomorphic nature (Carlquist, 1975).

Evidence from the present fossil wood features is in accord with the observations on the present day distribution of genus Terminalia and is further justified by the $\mathrm{V}$ value and the $\mathrm{M}$ index. Accordingly, a wet subtropical to tropical non-seasonal palaeoclimate for the site of growth of this species is deduced. It must not be forgotten, however that palaeoclimate inferences based on features of only one wood species are not as informative and hence as reliable as inferences based on the study of woods of the plant assemblage, which is therefore highly needed in case of the CPF. 

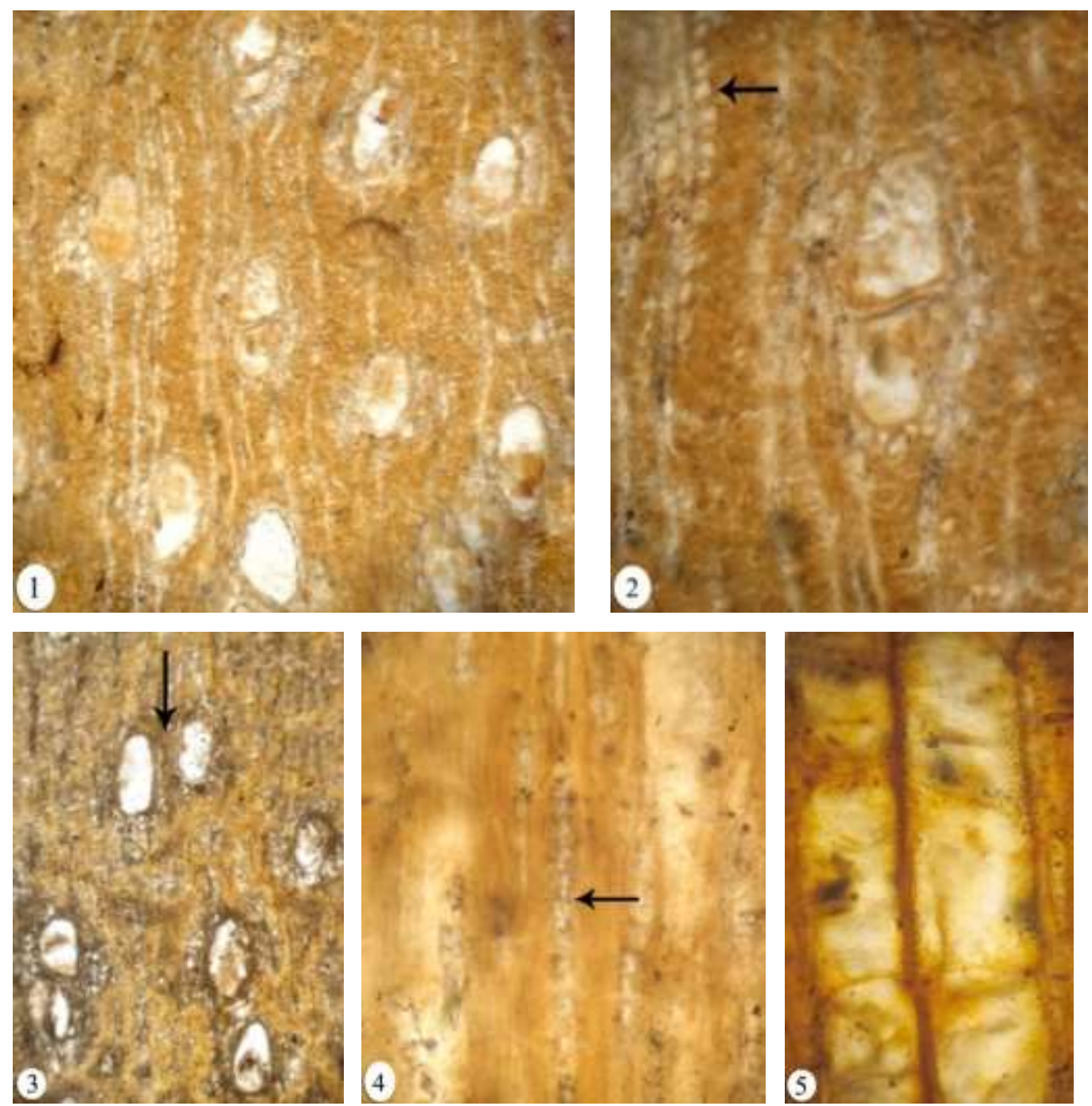

Plate I. T. edwardsii. 1: Cross-section showing diffuse-porous wood, vessels mostly solitary, vasicentric and diffuse parenchyma, x 20; 2: Cross-section showing diffuse parenchyma (arrow), x 25; 3: Cross-section showing confluent parenchyma connecting two vessels together (arrow), x 20; 4: Tangential longitudinal section showing uniseriate rays (arrow), x 50; 5: Longitudinal section showing medium-sized vessel elements, with horizontal end-walls, x 50 . 


\section{References}

Ahmed, B., Rajput, M. M. \& Soomro, N. 2007. Anogeissoxylon rehmanense sp. nov., a new fossil species of the family Combretaceae from Rehman Dhoro, District Jamshoro, Sindh, Pakistan. Pak. J. Bot., 39 (7): 2337-2344.

Andrews, H.N. 1961. Studies in palaeobotany. Wiley, New York and London, pp. 1-487.

APG III [Angiosperm Phylogeny Group III] 2009. An update of the Angiosperm Phylogeny Group classification for the orders and families of flowering plants: APG III. Botanical Journal of the Linnean Society 161, 105-121.

Bamford, M. 1999. Tertiary fossil woods from Vredendal, Southwestern Cape, South Africa. Mus. Roy. Afr. Cent. Tervuren, Ann. Sci. Econ. 25: 149-163.

Bkhat, H. 2012. Studies on the fossil mangroves of the Western Desert of Egypt. Ph.D. Thesis, Bot. Dept., Fac. of Sci., Ain Shams Uni., Cairo, Egypt, pp. 1-141.

Boureau, E. 1955. Etude paléoxylologique du Sahara (XXI): Sur un Terminalioxylon edengense $\mathrm{n}$. sp., de la pente sud de Edeng, au SudOuest de l'Adrar Tiguirirt (Sahara Soudanais). Bull. Mus. Nat. Hist. Nat., Paris, sér. 2, 27: 247-255.

Boureau, E. 1958. Etude paléoxylologique du Sahara (XXIV): Sur le Terminalioxylon fezzanense $\mathrm{n}$. sp., Combretaceae fossile du desert du Calancho (Fezzan oriental). Bull. Mus. Nat. Hist. Nat., Paris, sér. 2, 30: 321-327.

Boureau, E., Cheboldaeff-Salard, M., Koeniguer, J.C. \& Louvet, P. 1983. Evolution des flores et de la vegetation tertiaires en Afrique, au nord de 1' Equateur. Proc. $10^{\text {th }}$ AETFAT Congr., Pretoria, 1982. Bothalia 14 (3/4): 355-367.

Cantrill, D.J., Bamford, M.K., Wagstaff, B.E., Sauquet, H. 2013. Early Eocene fossil plants from the Mwadui kimberlite pipe, Tanzania. Rev. Palaeobot. Palynol. 196: 19-35.

Carlquist, S. 1975. Ecological strategies of xylem evolution. Univ. Calif. Press, Berkeley.

Carlquist, S. 1988. Comparative wood anatomy. Systematic, ecological and evolutionary aspects of dicotyledonous wood. Springer-Verlag, Berlin, Heidelberg, New York, Tokyo. 
Carruthers, W. 1870. On the petrified forest near Cairo. Geol. Mag. London, 7: 306-310.

Castañeda-Posadas, C., Calvillo-Canadell, L. \& Cevallos-Ferriz, S.R.S. 2009. Woods from Miocene sediments in Panotla, Tlaxcala, Mexico. Rev. Palaeobot. Palynol. 156: 494-506.

Chiarugi, A. 1933. Legni fossili della Somalia Italiana. Palaeontographica Ital. 32 (1): 97-167.

De Francheschi, D., Hoorn, C., Antoine, P-O, Cheema, I.U., Flynn, J.L., Lindsay, H.E., Marivaux, L., Métais, G., Rajpar, A.R. \& Welcomme, J-L. 2008. Floral data from the mid-Cenozoic of central Pakistan. Rev. Palaeobot. Palynol. 150: 115-129.

Dupéron-Laudoueneix, M. \& Dupéron, J. 1995. Inventory of Mesozoic and Cenozoic woods from Equatorial and North Equatorial Africa. Rev. Palaeobot. Palynol. 84: 439-480.

El-Saadawi, W.E. \& Kamal El-Din, M.M. 2004. Terminalioxylon species from Gebel Qatrani Formation at Widan El-Faras, Fayum, Egypt. Taeckholmia 24: 63-78.

El-Saadawi, W.E., Kamal El-Din, M.M., Attia, Y. \& El-Faramawi, M.W. 2011. The wood flora of the Cairo Petrified Forest, with five Paleogene new legume records for Egypt. Rev. Palaeobot. Palynol. 167: 184-195.

El-Saadawi, W.E.,Kamal El-Din, M.M., Wheeler, E., Osman, R., ElFaramawi, M.W., El-Noamani, Z. 2014. Early Miocene woods of Egypt. IAWA J. 35 (1), 35-50.

Fessler-Vrolant, C. 1980. Etude de quelques bois de Tunisie, C. r. 105e Congr. Nat. Soc. Sav., Caen, Sci. 1: 197-224.

Gregory, M., Poole, I. \& Wheeler, E.A. 2009. Fossil dicot wood names an annotated list with full bibliography. IAWA J., supplement 6, pp. 1220.

Gros, J.P., 1992. A synopsis of the fossil record of mimosoid legume wood. pp. 69-83 in: Herendeen, P.S. and Dilcher, D.L. (eds.), Advances in Legume systematic. 4. The Fossil Record. The Royal Botanic Gardens, Kew.

IAWA Committee, 1989. IAWA list of microscopic features for hardwood identification. IAWA J., 10: 219-332.

Insidewood, 2004-onwards. Published on the Internet. http://insidewood.lib.ncsu.edu/search. 
Kamal El-Din, M.M. 1996. Studies on a petrified wood at Gebel ElKhashab, Western Desert, Egypt. M.Sc. Thesis. Bot. Dept., Fac. of Sci., Ain Shams Uni., Cairo, Egypt, pp. 1-150.

Kamal El-Din, M.M. 2002. Bombacoxylon owenii (Carr.) Gottwald from Gebel Shabraweet, Eastern Desert, Egypt. Taeckholmia 22(1): 91-99.

Kappelman, J., Simons, E.L., Swisher III, C.C. 1992. New age determination for the Eocene-Oligocene boundary sediments in the Fayum Depression, Northern Egypt. The Journal of Geology 100 (6): 647-667.

Kräusel, R. 1939. Ergebnisse der Forschungsreisen Prof. E. Stromers in den Wüsten Ägyptens, IV. Die fossilen Floren Ägyptens: Die Fossilen Pflanzen Ägyptens. E-L Abh. Bayer. Akad. Wiss., Math.-Nat. Abt. N. F. 47: 1-140.

Lejal-Nicol, A. 1987. Flores nouvelles du Paléozoique et du Mésozoique de 1' Egypte et du Soudan septentrional. Berliner geowiss. Abh. (A) 50: 47-79.

Lemoigne, Y. 1978. Flores tertiaires de la haute vallée de L' Omo (Ethiopie). Palaeontographica Abt. B 165 (4-6): 89-157.

Lemoigne, Y., Beauchamp, J. \& Samuel, E. 1974. Etude paléobotanique des dépôts volcaniques d' âge tertiaire des bordures est et ouset du Système des Rifts éthiopiens. Geobios (Lyon) 7: 267-288.

Louvet, P.1973. Sur les affinities des flores tropicales ligneuses africaines tertiaire et actuelle. Bull. Soc. Bot. Fr. 120(9): 385-395.

Mädel-Angeliewa, E. \& Müller-Stoll, W.R. 1973. Kritische Studien über fossile Combretaceen-Hölzer: über Hölzer vom Typus Terminalioxylon G. Schönfeld mit einer Revision der bisher $\mathrm{zu}$ Evodioxylon Chiarugi gestellten Arten. Palaeontographica 142B (4/6): 117-136.

Metcalfe, C.R. \& Chalk, L. 1950. Anatomy of dicotyledons. Oxford. 1, pp. $1-724$.

Pan, A.D. 2007. The late Oligocene (28-27 Ma) Guang River Flora from the Northwestern plateau of Ethiopia. Ph.D. dissertation, Southern Methodist University, Dallas. pp. 1-193.

Said, R. 1971. Explanatory notes to accompany the geological map of Egypt. The Geological Survey of Egypt. 56: 1-123.

Schenk, A. 1883. Fossile Hölzer. Palaeontographica 30(2): 1-19.

Schenk, A. 1888. Fossile Hölzer aus Ostasien und Aegypten. K. Sven. Vetenskapsakad. Handl. 14, 1-24. 
Schönfeld, G. 1947. Hölzer aus dem Tertiär von Kolumbien. Abh. Senckenberg. Naturf. Ges. 475: 1-53 + pl. 1-5.

Schuster, J. 1910. Über Nicolien und Nicolien ähnlichen Hölzer. K. Sven. Vetenskapsakad.Handl. 45 (6): 1-18.

Singh, H., Prasad, M., Kumar, K. \& Singh, S.K. 2011. Paleobotanical remains from the Paleocene-lower Eocene Vagadkhol Formation, western India and their paleoclimatic and phytogeographic implications. Palaeoworld 20: 332-356.

Shukla, A., Mehrotra, R.C. \& Guleria, J.S. 2013. African elements (fossil woods) from the upper Cenozoic sediments of western India and their palaeoecological and phytogeographical significance. Alcheringa: An Australasian Journal of Palaeontology 37 (1): 1-18.

Tiwari, R.P., Mehrotra, R.C., Srivastava, G. \& Shukla, A. 2012. The vegetation and climate of a Neogene petrified wood forest of Mizoram, India. Journal of Asian Earth Sciences 61: 143-165.

Unger, F.J.A.N., 1858. Der versteinerte Wald bei Kairo und einige andere Lager verkieselten Hölzer in Ägypten. Sitz.-Ber.K.Akad.Wiss. M. $N$. Kl.Bd. 33, 209-233.

Wiemann, M.C., Dilcher, D.L. \& Manchester, S.R. 2001. Estimation of mean annual temperature from leaf and wood physiognomy. Forest Science 47 (2): 141-149.

Wolfe, J.A. \& Upchurch Jr., G.R. 1987. North American nonmarine climates and vegetation during the Late Cretaceous. Palaeogeography, Palaeoclimatology, Palaeoecology 61: 33-77.

Youssef, S.G. 1993. Studies on some Egyptian fossil woods. Ph.D. Thesis, Bot. Dept., Fac. of Sci., Benha Uni., Egypt, pp. 1-153. 